\title{
Madrasah di Bengkulu: Sejarah dan Perkembangannya dari Pergerakan Nasional Hingga Reformasi
}

\author{
Een Syaputra \\ Institut Agama Islam Negeri Bengkulu, Bengkulu, Indonesia \\ Jl. Raden Fattah, Pagar Dewa, Kota Bengkulu \\ eensyaputra23@gmail.com
}

\begin{abstract}
Madrasah in Bengkulu: History and Development since National Movement to Reformation. Since the beginning of the arrival of Islam in the archipelago, education has played an important and strategic role, especially in the process of Islamization or Islamization of various communities in the archipelago. This research is conducted by history method. The research undertaken are: heuristic, source criticism, interpretation, historiography. The results of the research showed that: First, Madrasah is an Islamic educational institution that was established in Bengkulu during the national movement, which was founded by religious organizations such as Muhammadiyah, PERTI and Jamiatul Khair; Second, An the begining of independence, the development of Madrasah in Bengkulu experienced many obstacles, especially experiencing the role of independence. The situation began to improve after the physical revolution was over, in which some Madrasah began to reactivate and new Madrasah also emerged; Third, During the New Order era, in Bengkulu began to emerge in several Madrasahs and several private Madrasahs which belonged to Islamic Boarding Schools. Although increasing in number, but qualitatively, Madrasas in the New Order era suffered a setback, mainly because they were unable to join public schools; Fourth, in the reformation era, Madrasas in Bengkulu City experienced a fairly rapid development. Also, there has been much increase with the rise of private Madrasas. In quality, some Madarasah and public and private Madrasa are also able to compete with Public Schools.
\end{abstract}

Keywords: Madrasah, Islamic Education, Bengkulu.

Abstrak: Madrasah di Bengkulu: Sejarah dan Perkembangannya sejak Pergerakan Nasional hingga Reformasi. Sejak awal kedatangan Islam di Nusantara, pendidikan telah memainkan peran penting dan strategis, terutama dalam proses pengislaman atau islamisasi berbagai masyarakat di Nusantara. Artikel ini bertujuan untuk mendeskripsikan sejarah dan perkembangan madrasah di Bengkulu sejak masa pergerakan kebangsaan hingga reformasi. Penelitian dilakukan dengan metode sejarah, yang terdiri dari empat tahap: heuristik, kritik sumber, interpretasi, dan historiografi. Berdasarkan penelitian yang dilakukan, diperoleh hasil bahwa: Pertama, madrasah merupakan lembaga pendidikan Islam yang telah berdiri di Bengkulu pada masa pergerakan nasional, yakni didirikan oleh organisasi keagaamaan seperti Muhammadiyah, PERTI dan Jamiatul Khair; Kedua, pada awal kemerdekaan, perkembangan madrasah di Bengkulu mengalami banyak hambatan, terutama mengalami peran kemerdekaan. Keadaan mulai membaik setelah revolusi fisik selesai, dimana beberapa madrasah mulai beraktivitas kembali dan juga muncul beberapa madrasah baru; ketiga, pada masa Orde Baru, di Bengkulu mulai muncul beberapa madrasah negeri dan beberapa madrasah swasta yang merupakan milik pesantren. Meskipun secara jumlah bertambah, namun secara kualitas, madrasah mada masa Orde Baru mengalami kemunduran, terutama karena kalah bersaing dengan sekolah umum; keempat, pada era Reformasi, madrasah di Kota Bengkulu mengakami perkembangan yang cukup pesat. Secara jumlah, banyak bertambah dengan munculnya madrasah swasta. Secara kualitas, beberapa madarasah negeri dan madrasah swasta juga mampu bersaing dengan sekolah umum.

Kata Kunci: Madrasah, Pendidikan Islam, Bengkulu. 


\section{Pendahuluan}

Sejak awal kedatangan Islam di Nusantara, pendidikan telah memainkan peran penting dan strategis, terutama dalam proses pengislaman atau islamisasi berbagai masyarakat di Nusantara. Melalui lembaga pendidikan, kemudian terbentuklah semacam jejaring antara guru dan murid, sehingga proses penyampaian risalah Islam (dakwah) dapat dilakukan dengan cepat dan menjangkau kawasan yang lebih luas. ${ }^{1}$

Pada fase awal pendidikan Islam di Nusantara, dikenal beberapa nama lembaga pendidikan seperti Surau, Meunasah, Dayah Pesantren, Langgar dan lain-lain. ${ }^{2}$ Baik Surau, Meunasah, Dayah, Pesantren, dan Langgar,semuanya telah memberikan kontribusi yang sangat berarti dalam perjalanan Islam di Nusantara dan juga tradisi keilmuan Islam, terutama sebelum pendidikan Barat di perkenalkan oleh pemerintah kolonial Belanda pada abad ke-19. Bahkan, tidak sedikit diantara ulama besar, para pejuang kemerdekaan dan tokoh-tokoh penting pada masa pergerakan keangsaan adalah produk dari lembaga pendidikan Islam tersebut.

Pada awal abad ke-20 muncul sebuah fenomena baru (modern) dalam dunia pendidikan Islam di Nusantara, yakni dengan munculnya Madrasah. ${ }^{3}$ Dikatakan sebagai fenomena baru (modern) karena pada era sebelumnya tidak ditemukan adanya informasi tentang keberadaan Madrasah di Nusantara. Yang ada hanyalahh lembaga pendidikan Islam tradisional seperti Surau di Minangkabau, Meunasah dan Dayah di Aceh serta Langgar dan Pesantren di Jawa dan Madura.

Secara umum ada dua faktor yang mendorong munculnya Madrasah di Nusantara pada awal abad ke-20. Pertama, gerakan pembaruan Islam. Gerakan pembaharuan Islam di Indonesia muncul pada abad ke 20 yang dilatarbelakangi oleh kesadaran dan semangat yang kompleks. Karel A. Steenbrink mengidentifikasi empat faktor pendukung gerakan pembaharuan Islam di Indonesia, yakni: 1) faktor keinginan untuk kembali pada AlQur'an dan Sunnah; 2) faktor semangat nasionalisme melawan Belanda; 3) faktor memperkuat basis gerakan sosial, ekonomi, budaya dan politik; dan 4) faktor untuk melakukan pembaharuan pendidikan Islam di Indonesia. ${ }^{4}$

Kedua, sebagai respon pendidikan Islam terhadap kebijakan pendidikan Belanda. Sejak awal dimulainya pemerintahan Hindia Belanda, banyak didirikan sekolahsekolah modern sebagaimana sistem pendidikan yang berkembang di Barat. Dalam perkembangannya, selain anakanak Belanda, di sekolah ini juga banyak anak-anak pribumi yang ikut mengenyam pendidikan. Dan kalau di lihat dari sistem yang diterapkan, sekolah-sekolah Belanda memang tergolong sekolah modern, baik dari segi kurikulum, fasilitas, dan lainlain. Sementara itu, pendidikan Islam disisi yang lain belum banyak melakukan perubahan. Akibatnya, sekolah Islam yang pada masa-masa sebelumnya sudah banyak berdiri mendapat tantangan. Selain itu, pendidikan Barat yang diperkenalkan oleh Belanda juga mempunyai muatan politis, terutama guna menekan kesadaran umat Islam. $^{5}$

Singkatnya, dapat dikatakan bahwa kehadiran Madrasah di Indonesia pada tahap awal tersebut merupakan sebuah upaya untuk menjembatani antara sistem pendidikan Islam tradisional dengan sistem pendidikan Barat yang diperkenalkan oleh kolonial Belanda. Hal ini sebagaimana diungkapkan oleh Arief Subhan bahwa Madrasah di Indonesia dapat dikatakan sebagai jembatan yang menghubungkan pendidikan sekuler (sekolah-sekolah Belanda) dengan pendidikan tradisional Pesantren. Madrasah menawarkan pendi-dikan umum sebagaimana ditawarkan sekolah umum. Pada saat yang sama Madrasah juga menawarkan pendidikan Islam sebagaimana ditawarkan pendidikan Islam tradisional Pesantren. Dari sekolah umum, Madrasah mengambil sistem pendidikan modern, dan dari Pesantren mengambil tradisi pembelajaran Islam. ${ }^{6}$ 
Lebih lanjut Maksum menjelaskan bahwa pada fase awal perkembangan Madrasah di Indonesia, yakni awal abad ke 20, Minangkabau dan Jawa adalah dua wilayah yang menjadi pelopor berdirinya Madrasah. ${ }^{7}$ Di Minangkabau, Madsarah kebanyakan dikembangkan oleh orang perorangan. Hal ini misalnmya terlihat dari apa yang dilakukan oleh Syech Abdullah Ahmad yang mendirikan Ababiah School pada tahun 1907 di Padang, Madras Scholls di Sungayang, Batu Sangkar yang didirikan oleh M. Thaib Umar pada tahun 1910, Diniyah School, yang didirikan oleh Zainuddin Labay El Yanusi di Padang Panjang pada tahun 1915, Sumatera Thawalib yang didirikan oleh Syech Abdul Karim Amrullah pada tahun 1921 dan lain sebagainya. ${ }^{8}$ Akan tetapi, agak berbeda dengan di Minangkabau, perkembangan Madrasah di Jawa lebih di dukung oleh semakin masifnya perkembangan perkumpulan-perkumpulan keagamaan seperti Muhammadiyah, Nahdatul Ulama, Persatuan Umat Islam dan lain-lain.

Perkembangan Madrasah di Minangkabau dan Jawa pada awal abad ke-20 tersebut juga menjalar hingga ke Bengkulu. Pada awal abad ke-20, di Bengkulu telah berdiri beberapa Madrasah yang didirikan oleh organisasi keagamaan seperti PERTI, Muhammadiyah dan Jamiatul Khair. ${ }^{9}$ Hal ini merupakan sebuah fenomena penting dalam sejarah pendidikan Islam di Bengkulu yang pada masa-masa sebelumnya tidak terlalu mengalami perkembangan. Tidak hanya itu, kehadiran Madrasah di Bengkulu pada pada masa pergerakan nasional telah pula memberikan sumbangan berarti bagi lahirnya tokoh-tokoh pergerakan kebangsaan yang kelak memainkan peran penting.

Pada masa setelah proklamasi kemerdekaan hingga menjelang Orde Baru, Madrasah di Bengkulu tetap menunjukkan eksistensinya. Hanya saja, oleh karena berbagai faktor, ada Madrasah yang terpaksa gulung tikar dan ada pula yang bermetamorposis menjadi Sekolah Negeri.
Pada masa Orde Baru, secara kuantitas, jumlah Madrasah di Bengkulu mengalami pertumbuhan yang cukup signifikan, terutama dengan munculnya beberapa Madrasah Negeri dan Madrasah Swasta yang dipelopori oleh Pondok Pesantren. Hanya saja, secara kualitas, dapat dikatakan bahwah Madrasah tertinggal dari Sekolah Umum yang secara jumlah pada saat itu mengalmi perkembangan yang luar biasa.

Pada masa reformasi, perkembangan MadrasahdiBengkulukembalimenemukan momentumnya. Madrasah yang pada masa Orde Baru banyak mengalami kepakuman secara perlahan mulai bangkit kembali. Selain itu, dengan semakin terbukanya ruang untuk mendirikan perkumpulan atau komunitas juga muncul banyak sekali Madrasah Swasta yang didirikan oleh orang perorangan, terutama Madrasah model baru yang mengadopsi sistem pendidikan pada Sekolah Islam Terpadu yang memgalami perkembangan pesat pasca runtuhnya Orde baru. Hingga tahun 2019, di Bengkulu tercatat ada sebanyak 26 Madrasah Ibtidaiyah, 9 Madrasah Tsanawiyah dan 9 Madrasah Aliyah.

Uraian di atas menegaskan bahwa perkembangan Madrasah di Kota Bengkulu selalu mengalami pasang surut pada setiap masanya, mulai dari zaman pergerakan nasional hingga zaman reformasi saat ini. Karena itu, melalui artikel ini penulis ingin melakukan kajian lebih lanjut tentang sejarah dan perkembangan Madrasah di Kota Bengkulu sejak zaman pergerakan nasional hingga zaman roformasi. Namun karena berbagai faktor, penelitian ini akan difokuskan pada perkembangan Madrasah di Kota Bengkulu.

Berdasarkanlatarbelakangdantujuan penelitian maka jenis dari penelitian atau metode yang digunakan dalam penelitian ini adalah penelitian sejarah. Adapun langkah-langkah dalam penelitian sejarah ini adalah terdiri dari empat tahap utama, yakni heuristik, kritik sumber, interpretasi dan historiografi. ${ }^{10}$

Untuk sumber tertulis, sumber primer yang akan digunakan adalah arsip 
yang tersimpan di Arsip Nasional Republik Indonesia. ${ }^{11}$ Kemudian akan dilakukan kritik eksternal dan internal. Kritik eksternal dilakukan aspek-aspek luar dan kritik internal menyangkut isi dari suatu sumber sejarah, apakah dapat diandalkan atau tidak. ${ }^{12}$

\section{Hasil dan Pembahasan}

\section{A. Fase Awal Madrasah di Bengkulu}

Kemunculan Madrasah di Bengkulu pada masa pergerakan nasional tidak terlepas dari perkembangan Madrasah di daerah lain, terutama Minangkabau dan Jawa. Bahkan dapat dikatakan bahwa Minangkabau dan Jawa adalah dua wilayah yang paling memberikan pengaruh bagi dunia pendidikan Islam di Bengkulu pada zaman pergerakan nasional. ${ }^{13}$ Selama masa pergerakan nasional, tercatat ada beberapa Madrasah yang berdiri di Kota Bengkulu.

Pertama, Madrasah Muhammadiyah Kebun Ross. Madrasah ini berdiri pada tanggal 30 April 1926, yakni sekitar 2 tahun sebelum Muhammadiyah cabang Bengkulu resmi berdiri. Salim Bella Pili dan Hardiansyah menjelaskan bahwa ada beberapa tokoh penting yang bertindak sebagai pendiridan pengembang Madrasah Muhammadiyah Kebun Ross, yakni: Almaini, H. Yunus Djamaludin, Achmad Kancil, Zainul Sailan, Napies, E. Saleha,, Hassan Din, Sulam, dan Oey Tjeng Hien atau H. Abdul Karim Oei. ${ }^{14}$

Adapun terkait sistem pendidikan yang diterapkan di Madrasah Muhammadiyah ini dapat dikatakan sudah modern. Hal tersebut sebagaimana keterangan Fatmawati dalam: Catatan Kecil Bersama Bung Karno dijelaskan bahwa pada saat ia mengeyam pendidikan disana (Sekolah Muhammadiyah), pendidikannya sudah tergolong maju, dimana selain pelajaran agama, juga ada pelajaran Bahasa Belanda, Pengetahuan Umum, serta Olahraga dan Rekreasi. ${ }^{15}$ Selain beberapa informasi tersebut di atas, juga didapati beberapa informasi terkait dengan Bung Karno selama masa pengasingan di Bengkulu. Dijelaskan bahwa selama masa pengasingan, Bung Karno terlibat aktif dalam kegatan Muhammadiyah di Bengkulu. Bahkan, pada saat pertama kali datang ke Bengkulu Bung Karno langsung menduduki posisi penting di Muahammadiyah, yakni sebagai Ketua Majlis Pendidikan dan Pengajaran. ${ }^{16}$ Selain itu juga dijelaskan bahwa Bung Karno juga terlibat sebagai pengajar di sekolah tersebut.

Kedua, Madrasah Jamiatul Khair. Menurut catatan Pijper, Jam'iyyat Khayr sudah berdiri pada tahun 1928. Hanya saja, meskipun telah berdiri pada tahun tersebut, barulah pada tahun1930 sekolahnya dapat/ selesai dibangun. ${ }^{17}$ Pada saat pertama kali dibangun, Madrasah ini terdiri dari empat kelas dengan total siswa sekitar 200 orang. Dan masih menurut catatan Pijper, pada saat awal perdiriannya, Madrasah ini terkesan kurang baik jika dibangdingkan dengan Madrasah di Pulau Jawa. ${ }^{18}$ Sebagian besar pelajarannya di isi oleh pelajaran agama seperti Qur'an, Tajwid, tata Bahasa Arab, ilmu Fiqih, ilmu tauhid, tafsir Qur'an. Adapun pelajaran umum yang juga diajarkan adalah berhitung, membaca dan menulis. ${ }^{19}$

Meskipun demikian, kehadiran Madrasah Jamiatul Khair kala itu dapat dikatakan modern dan mendapatan sambutan hangat dari masyarakat Bengkulu. Dikatakan modern karena di Madrasah ini tidak lagi menerapkan sistem pendidikan tradisional, dimana sudah menggunakan sistem klasikal dengan metode yang tidak hanya halaqoh. Di Madrasah ini tingkatan pelajarannya dibagi mejadi dua, yakni tingkat Ibtidakiyah (SD) dan tingkat Tsanawiyah (SMP). Untuk tingkat Ibtidakiyah lama belajarnya adalah 5 tahun sedangkan untuk Tsanawiyah lama belajarnya adalah 2 tahun. Jadi total lamanya belajar adalah 7 tahun. ${ }^{20}$

Untuk gurunya, pada umumnya di datangkan dari Sumatera Barat, Jamia'tul Chair Jakarta, Medan dan bahkan ada juga yang dari Kairo, Mesir. Dalam perkembangannya, tentu juga ada guru yang dari lokal yang diperbantukan, yakni 
seperti Ibrahim Hosen yang kelak menjadi salah satu tokoh penting di Bengkulu. ${ }^{21}$ Selain itu, sekolah ini kemudian juga banyak melahirkan tokoh-tokoh hebat lainnya, yakni seperti H. Nawawi, H. Aminudin Annas, H. Ridwan Mannai dan lain sebagainya. Namun sangat disayangkan bahwa usia sekolah ini tidak terlalu lama. Pada saat pendudukan Jepang, sekolah ini terkena likuidasi. Gedungnya kemudian digunakan sebagai gudang penyimpanan persedian pangan perang. ${ }^{22}$

Selain kedua Madarsah di atas, juga muncul Madrasah lain seperti:1) Tasyniatul Chair yang berdiri sebagai usaha dari usaha Pesatuan Tarbiatul Islamiyah yang mulamula didirikan di Kerkap Bengkulu Utara pada tahun 1934; 2) Muawwantulchair Arabische School yang didirikan oleh KH. Usman Hosen, Buatami, A. Khalik, Pangeran Dali dan lain-lain. ${ }^{23}$

\section{B. Madrasah Era Orde Lama}

Pasca proklamasi kemerdekaan, Indonesia yang telah memiliki pemerintahan sendiri dan terlepas dari campur tangan kolonial berusaha untuk melakukan perbaikan di berbagai aspek kehidupan, termasuk di bidang pendidikan. Berbagai kebijakan yang berhubungan perbaikan kualitas dan kuantitas pendidikan, termasuk pendidikan Islam mulai dirumuskan pada tingkat pusat. Meskipun demikian, karena dalam keadaan perang kemerdekaan (revolusi fisik), muncul berbagai macam hambatan yang kemudian membuat laju dunia pendidikan tidak berjalan semestinya.

Untuk konteks Bengkulu, geliat pendidikan, khsusnya pendidikan Islam pada masa perang kemerdekaan tidak banyak diketahui informasinya. Beberapa Madrasah dan sekolah Islam lainnya yang sudah ada pada zaman pergerakan, banyak yang mengalami kepakuman pada masa ini. Kalapun tetap berjalan, pelaksanaanya tidak berjalannormal.Halinimislanyayangdialami oleh Madrasah Muhammadiyah Kebun Ross, dimana aktivitas pembelajarannya harus terganggu akibat perang kemerdekaan. ${ }^{24}$

Keadaan mulai kembali secara normal pasca revolusi fisik. Beberapa Madrasah yang pada masa revolusi fisik sempat mengalami kepakuman secara berangsur mulai aktif kembali. Tidak hanya itu, pada tahun 1950-an di Bengkulu juga muncul Madrasah baru, baik yang didirikan oleh organisasi keagamaan maupun oleh perorangan. Pada tahun 1955 di Kota Bengkulu tercatat ada beberapa Madrasah yang masih aktif, yakni Mu'alimin Muhammadiyah Kebun Ross di bawah pimpinan Djalal Sajuthi, S.M.P.I PERTI di Malbro di bawah pimpinan M. Idris, Ibtidaiyah Muhammadiyah Kebub Ross di bawah pimpinan Mazni Hasan dan Tarbiyah Islamiyah PERTI Bengkulu di bawah pimpinan Zainul. ${ }^{25}$

Pada tahun 1955 beberapa Madrasah tersebut mendapat bantuan dana dari Kepala Kantor Pendidikan Agama. Adapun rinciannya adalah sebagai berikut:

Tabel 1.

Daftar Madrasah di Kota Bengkulu yang Menerima Bantuan pada Tahun 1955/1956

\begin{tabular}{lll}
\hline No & Nama Madrasah & Jumlah Bantuan \\
\hline 1 & $\begin{array}{l}\text { Mu'alimin } \\
\text { Muhammadiyah } \\
\text { Bengkulu }\end{array}$ & Rp. 4.464 \\
2 & $\begin{array}{l}\text { S.M.P.I PERTI } \\
\text { Bengkulu }\end{array}$ & Rp. 504 \\
3 & $\begin{array}{l}\text { Ibtidaiyah } \\
\text { Muhammadiyah }\end{array}$ & Rp. 1.020 \\
& $\begin{array}{l}\text { Kebun Ross } \\
\text { Tarbiyah }\end{array}$ & Rp. 1.112 \\
& Islamiyah PERTI & \\
& Bengkulu & \\
\hline
\end{tabular}

Sumber: Arsip Nasional RI.

Selain beberapa Madrasah di atas, juga tercatat dua Madrasah di Kota Bengkulu yang berdiri selama Orde Lama, yakni Madrasah Ibtidaiyah Darul Ulum Al-Islamy dan madrasah Tsanawiyah Nurul Huda. ${ }^{26}$ Pertama, Madrasah Ibtidaiyah Darul Ulum Al-Islamy. Kapan Madrasah ini mulai berdiri dan siapa 
yang mendirikannya penulis belum mendapatkan data yang akurat. Akan tetapi, dapat dipastikan bahwa Madrasah ini telah ada di Bengkulu sebelum tahun 1968. Hal ini didasarkan pada fakta bahwa pada tahun 1968 Madrasah ini berganti status menjadi Madrasah Ibtidaiyah Negeri 1 Kota Bengkulu dan menjadi vioner untuk madrasah negeri di Bengkulu. Artinya, dapat dipastikan bahwa sekolah ini sudah beropreasi jauh di tahun-tahun sebelum penegarian tersebut. ${ }^{27}$

Kedua, Madrasah Tsanawiyah Nurul Huda. Kapan berdirinya Madrasah ini juga tidak diketahui secara pasti. Qurniati berpendapat bahwa MTs Nurul Huda didirikan pada tahun 1967 oleh KH. Nawawi. ${ }^{28}$ Hal ini sejalan dengan pendapat Herry Noer Aly dkk bahwa MTs Nurul Huda didirikan oleh KH. Nawawi,H. Abdul Muis dan H. Abdul Thalib pada tahun 1960-an. ${ }^{29}$ Sama seperti MI Darul Ulum AlIslamy, MTs Nurul Huda kemudian juga berubah status menjadi MTs Negeri pada tahun 1968.

\section{Madrasah Era Orde Baru}

Pada tahun 1966 pemerintah mengeluarkankebijakanyang mengizinkan Madrasah Swasta untuk berubah status menjadi madrasah Negeri. Alhasil, banyak Madarsah Swasta yang kemudian bermetamorposis menjadi Madsarah Negeri, termasuk di Bengkulu. Dalam waktu yang singkat, di Indonesia terdapat 123 Madrasah Ibtidaiyah, 182 Madrasah Tsanawiyah dan 42 Madrasah Aliyah yang kemudian menjadi Madarsah Negeri. ${ }^{30}$

Pada tahun 1972 Presiden Soeharto memgeluarkan Keputusan Menteri No. 34 dan Insrstuksi Presiden No. 15 tahun 1974 yang mengatur Madrasah untuk di kelola oleh Menteri Pendidikan dan Kebudayaan. Tujuannya adalah untuk mendongkrak mutu pendidikan madarsah yang sebelumnya dianggap rendah. ${ }^{31}$ Akan tetapi, kebijakan ini kemudian menuai banyak kritik. Kalangan Islam pendukung sistem pendidikan Islam yang tergabung dalam Majelis Pertimbangan dan Pemberdayaan Pendidikan Agama dan
Keagamaan merasa keberatan terhadap kebijakan tersebut karena dianggap sebagai upaya dari sekelompok sekuler untuk mengurangi fungsi pendidikan Islam. Sebgai respon terhadap kritik ini, pada tahun 1975, tepatnya tanggal 24 maret 1975, dikeluarkan Surat Keputusan Bersama (SKB) Nomor 6/1975 dan Nomor 037/ U/1975 antara Menteri Agama, Menteri Pendidikan dan kebudayaan, dab Menteri Dalam Negeri tentang Peningkatan Mutu Pendidikan pada Madarsah. ${ }^{32}$

Berbagai kebijakan yang dibuat oleh pemerintah pusat sebagaimana di jelaskan di atas kemdian memberikan dampak yang besar pula pada perkembangan pendidikan Islam di Bengkulu, baik sebelum ataupun sesudah berdiri sendiri menjadi provinsi. Dampak tersebut adalah berupa berubahnya status beberapa Madrasah Swasta menjadi Madrasah Negeri.

Pertama, Madrasah swasta. Pada masa Orde Baru, beberapa Madrasah Swasta yang ada pada era sebelumnya berubah status menjadi Madsarah Negeri. MI Darul Ulum Al-Islamy berubah status menjadi MI Negeri Bengkulu, MTs Nurul Huda menjadi MTs Negeri Bengkulu dan ada juga MAN Bengkulu yang merupakan perubahan dari Pendidikan Guru Agama Negeri. Dengan berubahnya status tersebut, maka secara jumlah terjadi pengurangan pada Madrasah Swasta di Kota Bengkulu.

Meskipun demikian, juga ada beberapa Madrasah Swasta yang tetap bertahan pada bentuk semula. Ini antara lain apa yang terjadi pada Madrasah Muhammadiyah, dimana hingga tahun 1970, Madrasah Muhammadiyah di Kota Bengkulutetapeksisdanbahkanmenhalami pertumbuhan. Selain itu, jumlah Madrasah Swasta selama Orde Baru juga menghalami pertambahkan dengan berdirinya beberapa Pondok Pesantren yang juga mendirikan lembaga pendidikan Madrasah. Selama Orde Baru tercatat sebanyak tiga Pondok Pesantren yang berdiri di Kota Bengkulu yang masing-masing mendirikan lembaga pendidikan dalam bentuk Madrasah. Ketiga Pondok Pesantren tersebut adalah 
PP Pancasila yang kemudian mendirikan MI Pancasila, MTs Pancasila dan MA Pancasila, PP Darussalam yang mendirikan MI Darusalam, MTs Darussalam dan MA Darussalam dan PP Hidayatullah yang mendirikan MTs Hidayatullah. ${ }^{33}$

Kedua, Madrasah Negeri. Salah satu kebijakan untuk memajukan Pendidikan Islam adalah dengan menegrikan sekolah-sekolah swasta yang telah ada. Di beberapa daerah di luar Bengkulu, usaha semacam ini telah lama berjalan. Hanya saja untuk di Bengkulu, penegrian Madrasah Swasta ini baru pertama kali dilakukan pada tahun 1968. Pada tahun 1968, setidaknya ada dua Madrasah di Kota Bengkulu yang berubah statusnya dari madrasah swasta ke negeri, yakni MI Darul Ulum Al-Islamy dab MTs Nurul Huda. Madrasah Ibtidaiyah Darul Umum Al-Islamy TanjungAgungdinegerikanmenjadiMadrasah Ibtidaiyah Negeri Pagar Dewa berdasarkan Keputusan Menteri Agama Republik Indonesia No. 75 Tahun 1968. Adapun MTs Nurul Huda dinegrikan menjadi MTs Negeri Bengkulu berdasarkan Surat Keputusan Menteri Agama Republik Indonesia Nomor 76 tahun 1968. ${ }^{34}$

Untuk jenjang Madrasah Aliyah, Madrasah Aliyah Negeri di Bengkulu baru muncul untuk pertama kalinya pada tahun 1992, yakni dengan perubahan status Pendidikan Guru Agama Negeri (PGAN) menjadi Madrasah Aliyah Negeri pada tahun 1992 melalui Surat Keputusan Menteri Agama Republik Indonesia Nomor 42 Tahun 1992.35 Berikut ini adalah rincian jumlah Madrasah di Kota Bengkulu pada akhir Orde Baru:

Tabel 2.

Madrasah Negeri dan Swasta di Kota Bengkulu pada Masa Orde Baru

\begin{tabular}{lllll}
\hline No & $\begin{array}{c}\text { Level } \\
\text { Madrasa }\end{array}$ & \multicolumn{2}{c}{ Jenis Madrasah } & Total \\
\cline { 3 - 5 } & h & Swasta & Negeri & \\
1 & MI & 3 & 1 & 4 \\
2 & MTs & 5 & 1 & 6 \\
3 & MA & 5 & 1 & 6 \\
Jumlah & 13 & 3 & 16 \\
\hline
\end{tabular}

Sumber. Syaputra. (2019). hlm. 49.

\section{Madrasah Era Reformasi}

Sejak bergulirnya reformasi, perkembangan Madrasah di Bengkulu mengalami peningkatan yang cukup signifikan, terutama untuk kategori Madrasah Swasta. Adapun untuk Madrasah Negeri, jumlah peningkatannya tidak terlalu memadai. Jika sebelum reformasi, hanya ada satu MI Negeri, maka pada tahun 2003 bertambah menjadi dua buah MIN, yakni dengan berdirinya MIN 2 Kota Bengkulu yang beralmaat di Jl. Raden Fatah, Pagar Dewa, Kota Bengkulu. MI ini secara resmi berubah status menjadi MI Negeri berdasarkan Keputusan Menteri Agama RI Nomor 558 tahun 2003 tentang Penegerian 250 Madrasah. $^{36}$

Untuk level Madrasah Tsanawiyah juga bertambah lagi menjadi dua MTs Negeri, yakni MTs Negeri 2 Kota Bengkulu. Sebelumnya, MTs ini memang sudah lama beroperasi. Hanya saja statusnya masih merupakan kelas jauh dari MTs Negeri 1 Kota Bengkulu. Pada tahun 2003, barulah secara resmi berdiri sendiri menjadi MTs Negeri 2 Kota Bengkulu, yakni melalui Keputusan Menteri Agama RI Nomor 558 tahun 2003. ${ }^{37}$ Adapun utnuk level Madrasah Aliyah kasusnya sama dengan dua Madrasah sebelumnya, yakni merupakan kelas jauh dari MAN 1 Kota Bengkulu yang sudah mengalami kelebihan peserta didik. Untuk waktu penegeriannya sama dengan dua madrasah sebelumnya, yakni pada tahun 2003 melalui SK Menteri Agama RI Nomor 558 tahun 2003.38

Adapun untuk Madrasah Swasta, perkembangannya cukup mengalami peningkatan, dimana banyak berdiri Madrasah Swasta diberbagai level pendidikan. Untuk level dasar atau Madrasah Ibtidaiyah, hingga tahun 2007 terdapat sejumlah 9 Madrasah. Jumlah mengalami peningkatan tiga kali lipat dibandingkan dengan pada masa Orde Baru dimana MI Swasta hanya berjumlah 3 Madrasah.UntuklevelMadrasahTsanawiyah, pada tahun 2007 terdapat sebnayak 6 MTs, bertambah satu Madrasah jika dibandingkan dengan masa sebelumnya. Adapun untul level Madrasah Aliyah, jumlahnya justru mengalamipenurunanmenjadi4Madrasah. 
Ini dikarenakan adanya Madrasah Aliyah yang gulung tikar. ${ }^{39}$

Terakhir, pada tahun 2019, jumlah tersebut terus mengalami peningkatan, terutama untuk Madrasah Swasta yang semakin bertambah jumlahnya. Berikut ini adalah data tentang Madrasah Swasta dan Negeri di Kota Bengkulu tahun 2019:

Tabel 3.

Jumlah Madrasah di Kota Bengkulu Tahun 2019

\begin{tabular}{lcccc}
\hline \multirow{2}{*}{ No } & Level & \multicolumn{2}{c}{ Jumlah } & Jumlah \\
\cline { 3 - 4 } 1 & Madrasah & Swasta & Negeri & \\
2 & MI & 14 & 2 & 18 \\
3 & MTs & 7 & 2 & 9 \\
& MA & 7 & 2 & 9 \\
& Jumlah & 28 & 6 & 34 \\
\hline
\end{tabular}

Sumber: Dokumen Kantor Wilayah

Kementerian Agama Provinsi Bengkulu

\section{Kesimpulan}

Madrasah di Bengkulu muncul untuk pertama kali pada tahun 1920-an. Pada zaman ini, kemunculan Madrasah banyak dipelopori oleh organisasi keagmaan, terutama Muhammadiyah, PERTI dan Jamiatul Khair. Pada masa perang kemerdekaan, karena sebagian besar guru dan murid berusaha untuk menyelamatkan diri serta turut berjuang mempertahankan kemerdekaan, aktivitas pembelajaran di Madrasah mengalami kepakuman. Untuk beberapa Madrasah, aktivitas pembelajaran secara perlahan kembali normal setelah perang kemerdekaan selesai, yakni pada tahun 1950-an. Hingga menjelang Orde Baru, secara kuantitas jumlah Madrasah di Kota Bengkulu cukup mengalami perkembangan.

Pada masa orde baru, jumlah Madrasah di Kota Bengkulu kembali mengalami perkembangan, terutama dengan kemunculan beberapa Madrasah Negeri, seperti MI Negeri 1 Kota Bengkulu, MTs Negeri 1 Kota Bengkulu dan MA Negeri 1 Kota bengkulu. Selain itu, faktor lain yang juga membuat perkembangan Madrasah di Kota Bengkulu selama Orde Baru adalah karena kemunculan beberapa Pondok Pesantren yang menyelenggarakan pendidikanformaldalam bentukMadrasah. Meskipun demikian, perkembangan Madrasah di Bengkulu selama orde baru juga mengalami banyak hambatan, terutama karena kalah bersaing dengan sekolah umum.

Perkembangan Madrasah di Kota Beng-kulu kembali mendapatkan momentumnya pada tahun 2000-an. Pada masa ini, beberapa Madrasah Negeri yang sudah ada sebelumnya mengalami perkembangan pesat sehingga melahirkan Madrasah Negeri lainnya. Pada sisi yang lainnya, Madrasah Swasta juga mengalami perkembangan yang tidak kalah pesatnya. Beberapa Madrasah Sawsta muncul dengan gaya baru dan berhasil menarik hati masyarakat muslim. Beberapa diantaranya bahkan berhasil menjelma menjadi Madrasah unggulan di Kota Bengkulu.

\section{Catatan Akhir}

${ }^{1}$ Lihat Azra, Azyumardi. Jaringan Ulama Timur Tengah dan Kepulauan Nusantara Abad XVII dan XVII. Bandung: Mizan, 1994.

'Surau adalah lembaga pendidikan Islam tradisonal asal Minangkabau, Sumatera Barat. Adapun Meunanasah adalah lembaga pendidikan Islam tradisional asal aceh. Sedangkan Langgar lebih dikenal di Jawa dan Madura. Lihat Azra, Azyumardi. "Genealogy of Indonesian Islamic Education: Roles in the Modernization of Muslim Society." Heritage of Nusantara: International Journal of Religious Literature and Heritage4 No. 1 (2015): 85-114.

${ }^{3}$ Maksum. Madrasah Sejarah dan Perkembangannya. Jakarta: Logos, 1999.

${ }^{4}$ Steenbrink, Karel. Pesantren, Madrasah, Sekolah: Pendidikan Islam untuk Kurun Modern. Jakarta: LP3ES, 1986. hlm. 26-28

${ }^{5}$ Suminto, H. Aqib. Politik Islam Hindia Belanda: Het Kantoor voor Inlandsche Zaken. Jakarta: LP3ES, 1985.

${ }^{6}$ Subhan, Arief. Potret Madrasah di Dunia Islam: Keragaman, Kompleksitas, dan Persaingan Konsep Islam. Studia Islamika 14 No. 3 (2007): 559.

${ }^{7}$ Maksum. Op., Cit. 
Een Syaputra

Madrasah di Bengkulu: Sejarah dan Perkembangannya

${ }^{8}$ Rahman, Rini. "Modernisasi Pendidikan Islam Awal Abad 20: Studi Kasus di Sumatera Barat." Humanus 14 No. 2 (2015): 177. Lihat juga Nasril. "Modernisasi Pendidikan Islam Awal Abad XX: Studi Kasus di Sumatera Barat." Jurnal Pendidikan Islam 1 No. 2 (2017): 88-105.

'Syaputra, Een. Dari Madrasah dan Pesantren Hingga Sekolah Islam Terpadu: Dinamika Lembaga Pendidikan Islam di Bengkulu Pasca Kemerdekaan hingga Reformasi. Jakarta: Direktorat Sejarah, 2019.

${ }^{10}$ Gottscalk, Luis. Mengerti Sejarah. Terj. Nugroho Notosusanto. Jakarta: UI Press, 2005. Lihat juga Sjamsuddin, Helius. Metodologi Sejarah. Yogyakarta: Ombak, 2007.

${ }^{11}$ Lohanda, Mona. Membaca Sumber Menulis Sejarah. Yogyakarta: Ombak, 2011: 2.

12Sjamsuddin, Helius. Op., Cit: 132-254. Lihat juga Kuntowijoyo. Pengantar Ilmu Sejarah. Yogyakarta: Tiara Wacara, 2013: 77-78.

${ }^{13}$ Lihat Pijper. Pragmenta Islamica: Beberapa Studi Mengenai Sejarah Islam di Indonesia Awal Abad XX. Jakarta: UI Press, 1987. Lihat juga Ismail dan Aryati, Aziza. "Eksistensi Ulama Minang dan Ulama Jawa dalam Mengembangkan Islam di Bengkulu." Tsaqofah \& Tarikh 4 No. 2 (2019): 151-153.

${ }^{14}$ Pili, Salim. B\& Hardiansyah. Napak Tilas Sejarah Muhammadiyah Bengkulu (Membangun Islam Berkemajuan di Bumi Raflesia). Yogyakarta: Valia Pustaka, 2019: 205.

${ }^{15}$ Fatmawati Soekarno. Catatan Kecil Bersama Bung Karno. Jakarta: Dela Rohita, 1978.

${ }^{16}$ Farida. "Pergumulan Soekarno dan Muhammadiyah di Bengkulu Tahun 19381942." Skripsi. Jurusan Sejarah Peradaban Islam UIN Sunan Ampek Surabaya, 2018: 52. Lihat juga Pilli \& Hardiansyah. Op., Cit: 111; Setiyanto, Agus. Op., Cit:143.

${ }^{17}$ Lihat Pijper. Op. Cit:138-139.

${ }^{18}$ Ibid

${ }^{19}$ Dalam catatan Pijper dijelaskan bahwa di Madrasah ini jam sekolah di bagi menjadi dua, yakni pagi dan sore. Pada pagi hari diberikan pelajaran lengkap khsusn untuk murid yang memang hanya mengikuti sekolah tersebut. Sedangkan untuk sore hari pelajaran diperutntukkan bagi murid-murid yang siang harinya mengikuti pelajaran di sekolah Guburnement. Lihat Pijper, Op.Cit: 138.

${ }^{20}$ Lihat Depdikbud RI. Sejarah Pendidikan Daerah Bengkulu. Jakarta: Depdikbud, 1981: 51.
${ }^{21}$ Amnur, Amnah Qurniari. "Sejarah Perkembangan pendidikan Islam di Bengkulu Abad XX." Disertasi. Pascasarjana Universitas Islam Negeri Sunan Kaijaga Yogyakarta, 2017.

${ }^{22} \mathrm{Ibid}$

${ }^{23}$ Depdikbud. Op. Cit. Lihat juga Musofa, Ahmad Abas. "Sejarah Islam di Bengkulu Abad ke XX M: Melacak Tokoh Agama, Masjid dan Lembaga (Organisasi) Islam." Tsaqofah \& Tarikh 1, No. 2 (2016): 122.

${ }^{24}$ Amnah Qurniati. Op., Cit:235.

${ }^{25}$ Syaputra. Op., Cit: 39.

${ }^{26}$ Ibid

${ }^{27}$ Ibid

${ }^{28}$ Qurniati. Op., Cit.

${ }^{29}$ Aly dkk. Op., Cit.

${ }^{30}$ Lihat Prihadyoko, Imam. Pendidikan Madrasah dan Hancurnya sebuah Otoritas Masyarakat. Kompas, 22/09/2001.

${ }^{31}$ Pratama, Yoga A. (2019). "Integrasi Sistem Pendidikan Madrasah dalam Sistem Pendidikan Nasional: Studi Kebijakanm Pendidikan Madrasah di Indonesia." AlTadzkiyyah: Jurnal Pendidikan Islam 10 No. 1 (2019): 103

${ }^{32}$ Kosim, Muhammad. "Madrasah di Indonesia: Pertumbuhan dan Perkembangan." Tadris 2, No. 1 (2007): 52.

${ }^{33}$ Syaputra. Op. Cit.

${ }^{34}$ Lihat Surat Keputusan Menteri Agama RI Nomor. 75 tahun 1968.

${ }^{35}$ Lihat SK Menteri Agama Republik Indonesia Nomor 42 Tahun 1992.

${ }^{36}$ Lihat Surat Keputusan Menteri Agama RI Nomor. 558 Tahun 2003 tentang Penegraun 250 Madrasah.

${ }^{37}$ Syaputra. Op., Cit.

${ }^{38}$ Lihat Keputusan Menteri Agama RI Nomor 558 tahun 2003 tentang Penegerian 250 Madrasah.

${ }^{39}$ Syaputra. Op. Cit.

\section{Daftar Referensi}

Aly, Herry. N. dkk. "Genealogi dan Jaringan Ulama di Kota Bengkulu:Studi Terhadap Asal Usul Keilmuan dan Kontribusinya dalam Pengembangan Pendidikan Islam." Laporan Penelitian. LPPM IAIN Bengkulu, 2014.

Amnur, Amnah. Q. “Sejarah Perkembangan pendidikan Islam di Bengkulu Abad XX." Disertasi. Pascasarjana Universitas Islam Negeri Sunan 
Kaijaga, Yogyakarta, 2017.

Azra, Azyumardi. (1994). Jaringan Ulama Timur Tengah dan Kepulauan Nusantara Abad XVII dan XVII. Bandung: Mizan, 1994.

Azra, Azyumardi. "Genealogy of Indonesian Islamic Education: Roles in the Modernization of Muslim Society." Heritage of Nusantara: International Journal of Religious Literature and Heritage 4, No. 1 (2015): 85-114.

Depdikbud RI. Sejarah Pendidikan Daerah Bengkulu. Jakarta: Depdikbud. 1981.

Farida. "Pergumulan Soekarno dan Muhammadiyah di Bengkulu Tahun 1938-1942." Skripsi. Jurusan Sejarah Peradaban Islam UIN Sunan Ampel, Surabaya, 2018.

Fatmawati. Catatan Kecil Bersama Bung Karno. Jakarta: Dela Rohita, 1978.

Gottscalk, Louis. Mengerti Sejarah. Terj. Nugroho Notosusanto. Jakarta: UI Press, 2005.

Ismail dan Aryati, Aziza. "Eksistensi Ulama Minang dan Ulama Jawa dalam Mengembangkan Islam di Bengkulu." Tsaqofah \& Tarikh: Jurnal Kebudayaan dan Sejarah Islam 4 No. 2 (IAIN Bengkulu 2019): 145-162. http:/ / dx.doi.org/10.29300/ttjksi.v4i2.2468

Junaedi, Mahfud. "Madrasah: Dari Nizamiyyah hingga Pesisiran Jawa. "NADWA: Jurnal Pendidikan Islam 8, No. 1 (2014): 99-101.

Kuntowijoyo. Pengantar Ilmu Sejarah. Yogyakarta: Tiara Wacara, 2013.

Lohanda, Mona. Membaca Sumber Menulis Sejarah. Yogyakarta: Ombak, 2011.

Maksum. Madrasah Sejarah dan Perkembangannya. Jakarta: Logos, 1999.

Musofa, Ahmad Abas. "Sejarah Islam di Bengkulu Abad ke XX M: Melacak Tokoh Agama, Masjid dan Lembaga (Organisasi) Islam." Tsaqofah \& Tarikh: Jurnal Kebudayaan dan Sejarah Islam 1, No. 2 (IAIN Bengkulu 2016): 115-130.https:/ / dx.doi.org/10.29300/ ttjksi.v1i2.720

Pijper. Pragmenta Islamica: Beberapa Studi Mengenai Sejarah Islam di Indonesia
Awal Abad XX. Jakarta: UI Press, 1987.

Pili, Salim. B \& Hardiansyah. Napak Tilas Sejarah Muhammadiyah Bengkulu (Membangun Islam Berkemajuan di Bumi Raflesia). Yogyakarta: Valia Pustaka, 2019.

Pratama, Yoga. A. "Integrasi Sistem Pendidikan Madrasah dalam Sistem PendidikanNasional:StudiKebijakanm Pendidikan Madrasah di Indonesia." Al-Tadzkiyyah: Jurnal Pendidikan Islam 10, No. 1 (2019): 95-112.

Prihadyoko, Imam. “Pendidikan Madrasah dan Hancurnya sebuah Otoritas Masyarakat." Kompas, 22/09/2001.

Rohimin, dkk.Sejarah Masuk dan Berkembangnya Islam di Bengkulu. Yogyakarta: Pustaka Pelajar, 2017.

Rahman, Rini (2015). Modernisasi Pendidikan Islam Awal Abad 20: Studi Kasus di Sumatera Barat. Humanus, 14 (2), 174-182.

Setiyanto, Agus.“Jejak Sejarah Bung Karno di Bengkulu." Tsaqofah \& Tarikh: Jurnal Kebudayaan dan Sejarah Islam 3 No. 2 (IAIN Bengkulu 2018): 130-148.

Sjamsuddin, Helius. Metodologi Sejarah. Yogyakarta: Ombak, 2007.

Steenbrink, Karel. Pesantren, Madrasah, Sekolah: Pendidikan Islam untuk Kurun Modern. Jakarta: LP3ES, 1986.

Subhan, Arief. "Potret Madrasah di Dunia Islam: Keragaman, Kompleksitas, dan Persaingan Konsep Islam." Studia Islamica 14 No. 3 (2007): 547-565.

Surat Keputusan Menteri Agama RI, Nomor 75 Tahun 1968.

Surat Keputusan Menteri Agama Republik Indonesia Nomor 42 Tahun 1992.

Surat Keputusan Menteri Agama RI Nomor 558 tahun 2003 tentang Penegerian 250 Madrasah.

Syaputra,Een.DariMadrasahdanPesantren hingga Sekolah Islam Terpadu: Dinamika Lembaga Pendidikan Islam di Bengkulu Pasca Kemerdekaan hingga Reformasi. Jakarta: Direktorat Sejarah, 2019. 